\title{
MANUFACTURE OF SOIL-CEMENT BRICKS WITH THE ADDITION OF SUGARCANE BAGASSE ASH
}

\author{
Rodrigo A. Jordan ${ }^{1}$, Matheus V. Da Costa ${ }^{2 *}$, Elton A. S. Martins ${ }^{1}$, Maxer A. Rosa ${ }^{3}$, Alfredo Petrauski ${ }^{3}$ \\ ${ }^{2 *}$ Corresponding author. Universidade Federal da Grande Dourados/ Dourados - MS, Brasil. E-mail: matheuscosta@ufgd.edu.br \\ ORCID ID: https://orcid.org/0000-0002-0294-3569
}

\section{KEYWORDS}

ash, compressive strength, soil-cement.

\begin{abstract}
The objective of this study is to evaluate the effect of sugarcane bagasse ash on the compressive strength and water absorption index of soil-cement bricks. The ash was sieved without chemical and/or physical treatment to reflect the use of this material in real manufacturing processes. The addition of natural ash decreased the quality of the bricks, reducing the compressive strength and increasing the water absorption index.
\end{abstract}

\section{INTRODUCTION}

Brazil is the largest global producer of sugarcane, sugar, and ethanol (Gilio \& Castro, 2016). According to data released by Novacana (2016), sugarcane yield in the state of Mato Grosso do Sul (MS) in the 2015/2016 harvest was 48.557 million tons, $12.99 \%$ higher than in the previous harvest (42.974 million tons).

Sugarcane processing generates waste, including the ash from the burning of the sugarcane bagasse used in the boilers of processing plants.

Cortez (1992) and Tommaselli et al. (2011) reported that the amount of bagasse varied according to the sugarcane fiber content and was approximately 260 kilos of bagasse per ton of processed sugarcane. Approximately 25 kilograms of ash are generated for every ton of incinerated bagasse.

The characteristics of the ash depend on the burning conditions of the bagasse, and the burning temperature and length of burning may also affect the characteristics of ash, including pozzolanicity, which cannot be determined in burning processes without temperature control (Almeida et al., 2015).

The construction and demolition industry is responsible for $40 \%$ of the energy consumed worldwide and for one-third of the emissions of greenhouse gases (Muñoz et al., 2016), which warrants finding solutions that can reduce this impact by reusing materials that would otherwise be discarded, including natural ash.

Several studies attempted to incorporate sugarcane bagasse ash (SCBA) into concrete and mortar for various applications, including bricks (Bezerra et al., 2017; Geerthana et al., 2016; Berenguer et al., 2016; Sivakumar \& Mahendran, 2014). Kazmi et al. (2016) evaluated the addition of ash from rice husk and sugarcane bagasse in clay bricks and found that the compressive strength and modulus of rupture decreased with the addition of these materials compared to untreated bricks. However, these two parameters were considered satisfactory in treated bricks because the values were within the ranges established by the norms.

Faria et al. (2012) analyzed the use of SCBA as a raw material in the manufacture of clay bricks, replacing $20 \%$ of clay with SCBA. The results demonstrated that SCBA could be used as filler in bricks, indicating that the use of this material is sustainable.

Valenciano \& Freire (2004) evaluated the physical and mechanical characteristics of mixtures of soil, cement, and SCBA. Different cement-ash combinations were analyzed, and the compressive strength was measured. The results indicated the possibility of replacing up to $20 \%$ of the cement with SCBA without decreasing the compressive strength of the material.

Fernandes et al. (2015) assessed the feasibility of adding SCBA as a partial substitute of small aggregate particles in concretes and found that the compressive strength of concrete with $20 \%$ of SCBA was equivalent or higher than that of the reference material, demonstrating the efficiency of SCBA as a mineral additive in concrete.

Soil-cement bricks are produced by pressing and do not require subsequent burning, and therefore are designated "green bricks" (Castro et al., 2016). Estabragh et al. (2011) reported that soil-cement bricks could be used for slope and landfill protection and also as a pavement base in highways.

Leonel et al. (2017) observed that brick resistance was affected by the composition, particle size distribution, and activity of each component of the mixture.

The objective of this study was to evaluate the effect of natural SCBA without pretreatment on the compressive strength and water absorption of soil-cement bricks.

\footnotetext{
${ }^{1}$ Universidade Federal da Grande Dourados/ Dourados - MS, Brasil.

${ }^{3}$ Universidade Estadual do Oeste do Paraná/ Cascavel - PR, Brasil.

Received in: 2-20-2018

Accepted in: 12-7-2018
} 


\section{MATERIAL AND METHODS}

\section{Study site}

The experiment was conducted on the campus of the Federal University of Grande Dourados (Universidade Federal da Grande Dourados-UFGD) from May 2014 to July 2015 in the municipality of Dourados, MS, Brazil. The water absorption and compressive strength tests were carried out in the Laboratory of Structure and Materials of Engineering (Laboratório de Estrutura e Materiais da Engenharia-LEME) of the State University of the West of Paraná (Universidade Estadual do Oeste do ParanáUNIOESTE) in Cascavel, state of Paraná, Brazil.

\section{Materials}

The materials used for manufacturing soil-cement bricks were a mixture of sandy soil (SS) from the municipality of Itahum and clayey soil (CS) collected on the UFGD campus; the ratio of the mixture was 1.0 to 0.8 , respectively. The composition of the collected soils was determined at the Agricultural Monitoring Company (Empresa de Monitoramento Agropecuário Ltda-EMA) in Dourados, MS, Brazil (Table 1).
TABLE 1. Granulometric analysis of the collected soils.

\begin{tabular}{cccc}
\hline Soil & Sand $(\%)$ & Silt $(\%)$ & Clay $(\%)$ \\
\hline 1 & 86 & 2.5 & 11.5 \\
2 & 16.4 & 18.1 & 65.5 \\
\hline
\end{tabular}

Rodrigues \& Holanda (2013), Machado \& Araújo (2014), and Silva et al. (2014) reported that the most suitable soils for producing bricks had a sand content of 45$50 \%$. The possibility of mixing two or more soils, or even adding coarse sand, should be considered for soils with these characteristics. Therefore, the two types of soils were combined to reach the recommended percentage of sand and improve the quality of the mixture used to make the bricks using a material that otherwise would be discarded.

After collection, the soils were dried outdoors for four days. After drying, the soils were sieved in a $4.8-\mathrm{mm}$ mesh sieve to standardize the granulometry and remove extraneous materials, which were unnecessary and detrimental to the performance of the test.

Cement CP-II-E-32 and SCBA from the NovAmérica Plant located in the municipality of Caarapó, MS, were used (Figure 1).

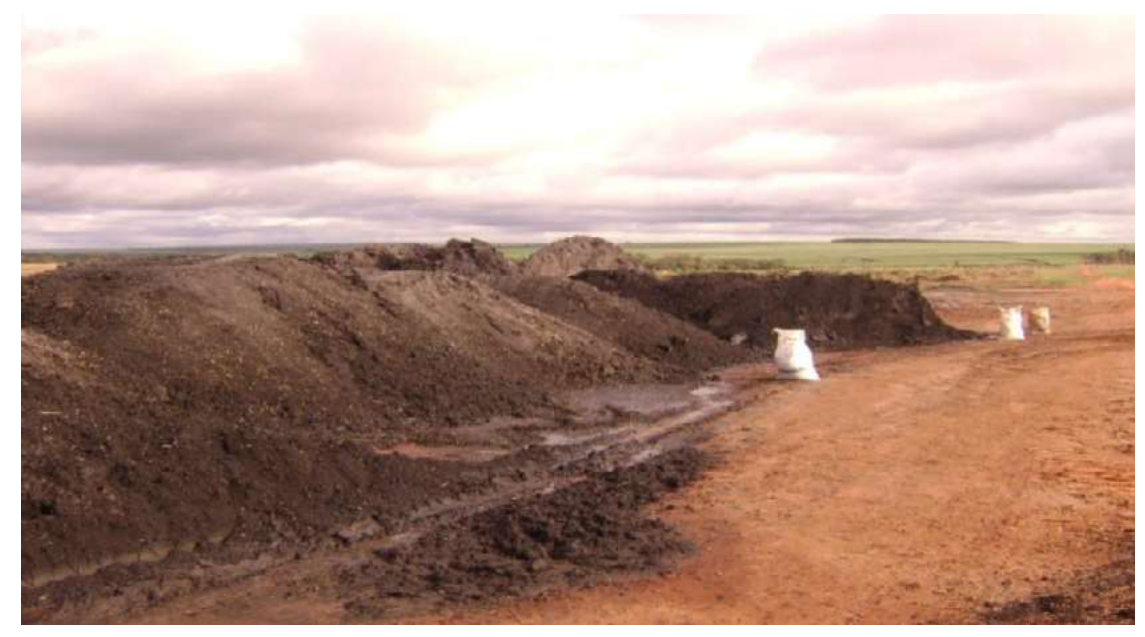

FIGURE 1. Collection site of sugarcane bagasse ash in the NovAmérica Plant

According to data supplied by the mill, bagasse was burned at a temperature of $600{ }^{\circ} \mathrm{C}$. Bagasse was stored in an open place and, for this reason, presented high moisture content. Not all the material was burned.

This material was dried in open air and sieved under the same conditions described above for removing coarser particles and residues.

\section{Mixture preparation and brick manufacture}

For brick manufacture, the amount of cement in the composition was kept constant, and $0 \%, 30 \%$, or $40 \%$ of the composition of the soils was replaced with SCBA. The following cement-soil-ash ratios were used (in volume):

- (1-6-4) (composition 1);

- $\quad(1-7-3)$ (composition 2);

- (1-10-0) (composition 3).

The study used a completely randomized block design with a $3 \times 2$ factorial scheme, six treatments, and 13 replicates, totaling 78 bricks, including 26 bricks per composition, and 13 bricks per treatment. Statistical analyses were performed using analysis of variance and Tukey's test.
For brick manufacturing, the SS and CS were mixed, and cement and SCBA were added. After mixture homogenization, water was added in a proportion of $10 \%$ of the mass of the soil-cement-ash mixture. The bricks were molded using a hand press following the procedures described in NBR 10833 according to ABNT (2013a) and placed on wooden pallets for curing. Water curing was started six hours after molding and was performed daily at 9:00 am and 4:00 pm for seven days.

Two types of cure were used: one in the open air (treatment 1) and the other in a protected environment (treatment 2). The bricks in the protected environment were covered by a black tarp and underwent the same curing process described above.

\section{Tests}

\section{Compressive strength test}

The compressive strength test was performed according to the procedures described in NBR 10836 (ABNT, 2013c). The length, width, and height of all samples were measured according to NBR 10834 guidelines (Figure 2) (ABNT, 2013b). 


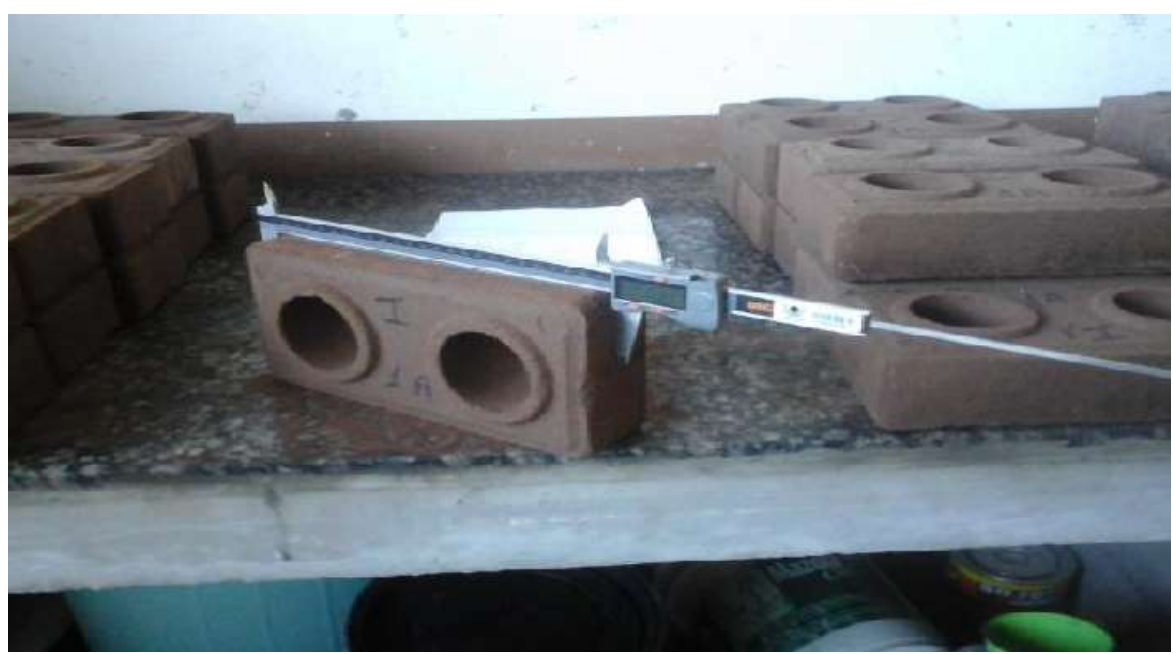

FIGURE 2. Measurement of the bricks according to NBR 10834 (ABNT, 2013b)

After the measurements, the bricks were capped with Portland cement paste with a resistance higher than that of the bricks (Figure 3). After hardening of the cap, the samples were immersed in water for 24 hours and removed immediately before the tests were performed.

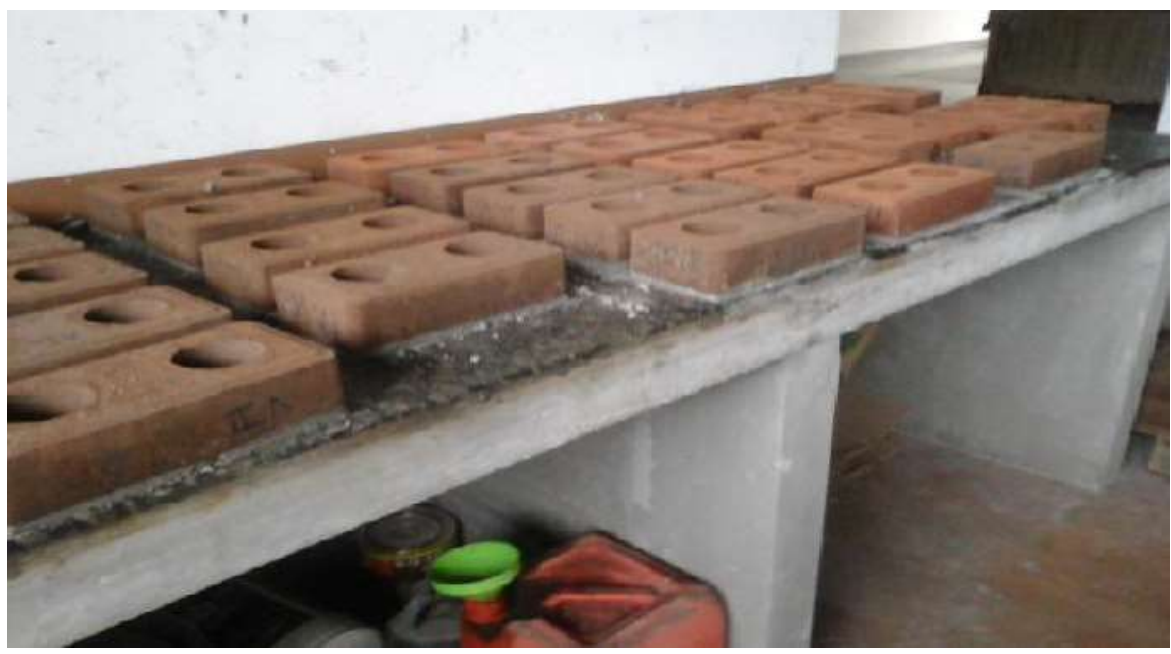

FIGURE 3. Bricks capped with Portland cement paste.

At the time of the compressive strength test, the bricks were removed from the water, dried with a lightly moistened cloth, and pressurized (Figure 4).

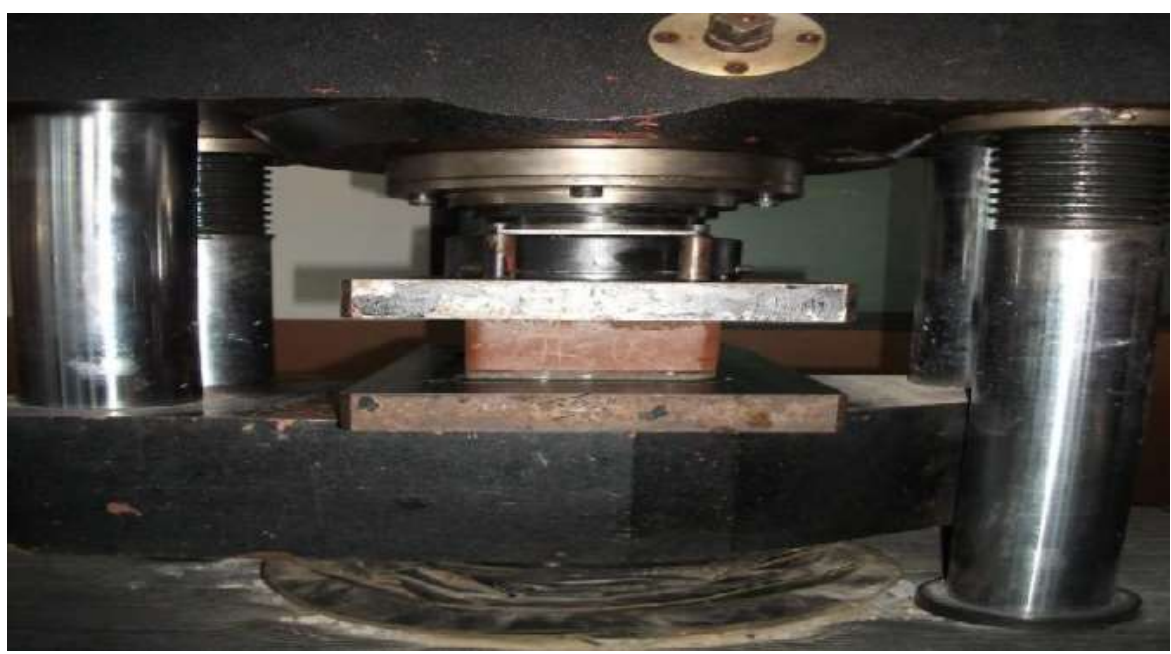

FIGURE 4. Compressive strength test1 


\section{Water absorption test}

The water absorption test was performed according to the procedures described in NBR 10836 (ABNT, 2013c). First, the samples were dried in an oven at a constant temperature of $105^{\circ} \mathrm{C}$ and weighed until constant mass was obtained. After that, the samples were immersed in water at room temperature for $24 \mathrm{~h}$ (Figure 5). The bricks were dried with a damp cloth, and the saturated mass was determined.

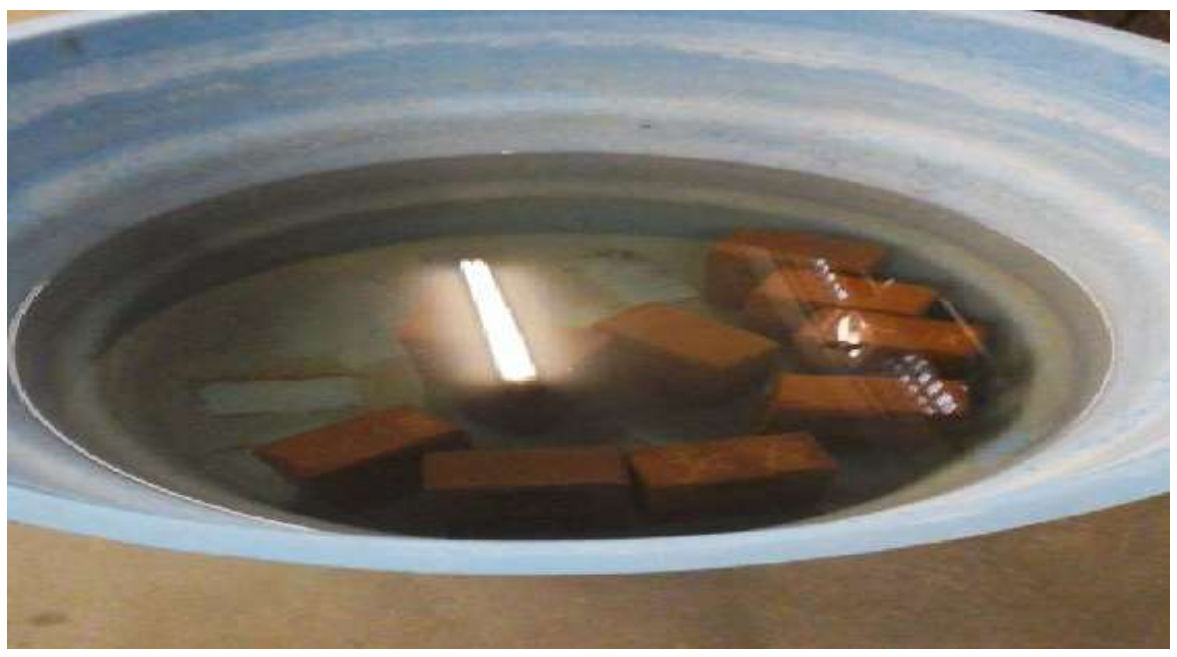

FIGURE 5. Bricks immersed in water to perform the absorption test.

\section{RESULTS AND DISCUSSION}

\section{Compressive strength}

NBR 10834 recommends a mean compressive strength of $\geq 2.0 \mathrm{MPa}$ and an absolute value of $\geq 1.7 \mathrm{MPa}$ for the tested samples (ABNT, 2013b). The measurements did not reach the minimum values established by the norm, not even composition 3, which did not contain SCBA. Some reference samples reached an absolute compressive strength of $>1.7 \mathrm{MPa}$, but the result was considered unsatisfactory because the average values did not reach 2.0 $\mathrm{MPa}$. The mean compressive strength values of different mixtures are shown in Figure 6.

\section{Mean compressive Strength}

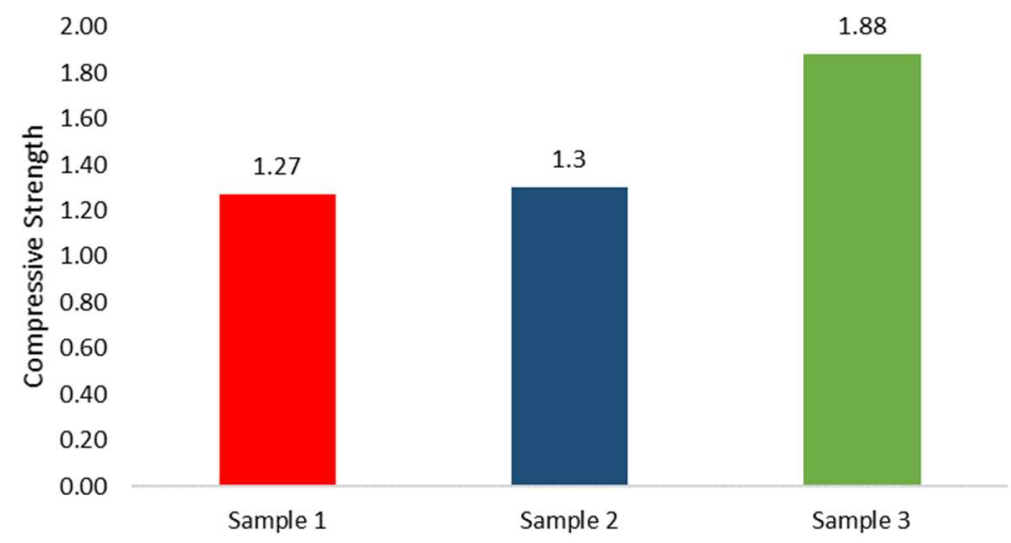

FIGURE 6. Mean compressive strength.

It is of note that the strength of the materials containing SCBA was lower than that of materials without SCBA. This result was because the ashes were not treated, producing a material with voids and variable granulometry, compromising the quality of the mixture and leading to values lower than those established by the norm.

Almeida et al. (2015) observed that SCBA particles, when properly treated, had a filler effect and served to fill the micropores of the mixture, reducing the number of voids, contributing to the maintenance of compressive strength. The opposite effect was observed in our samples, with the increase in the void index and a consequent decrease in compressive strength.

Kazmi et al. (2016) found that the compressive strength of clay bricks was decreased by incorporating rice husk ash and SCBA into the bricks, and the addition of ash increased material porosity, reducing the strength of the bricks from 8.38 MPa to 5.10 MPa. Ferrari et al. (2014) reported that the compressive strength of soil-cement bricks was decreased by $50 \%$ by replacing $20 \%$ of cement with 
SCBA compared with mixtures not containing SCBA, and the minimum strength recommended by the norm was not achieved.

Other contributing factors for the low compressive strength of the bricks were the mixing of SS and CS and the non-measurement of normative parameters for confirming the feasibility of using SS + CS, including granulometry, liquidity limit, and plasticity limit. According to the soil mixtures used and the respective substitution of these by ash, the sampled materials had similar compositions:

- Composition 1: 75\% sand, 5\% silt, and 20\% clay;

- Composition 2: 70\% sand, 6\% silt, and 24\% clay;

- Composition 3: 58\% sand, 9\% silt, and 33\% clay;

Ferrari et al. (2014) used a soil containing 78\% sand, $3 \%$ silt, and $19 \%$ clay for producing soil-cement bricks. This soil was prepared according to the recommendations of NBR 6457 without the addition of ash, and compressive strength was higher than the recommended value $(2.0 \mathrm{MPa})$ at 7 days of age. The mean compressive strength of the bricks not containing SCBA was $1.88 \mathrm{MPa}$, which was lower than the $2.0 \mathrm{MPa}$ established by the norm, confirming the assertion that this soil mixture was not satisfactory compared to the reference material.

The significance of the statistical analysis of the compressive strength test results was high $(\mathrm{p}<0.05)$ using Tukey's test.

\section{Water absorption}

According to NBR 10834, the samples should present a mean water absorption of $\leq 20 \%$ and an absolute value of $\leq 22 \%$ at 28 days of age (ABNT, 2013b). The values for all tested samples were within the established limits (Figure 7).

\section{Mean water absorption}

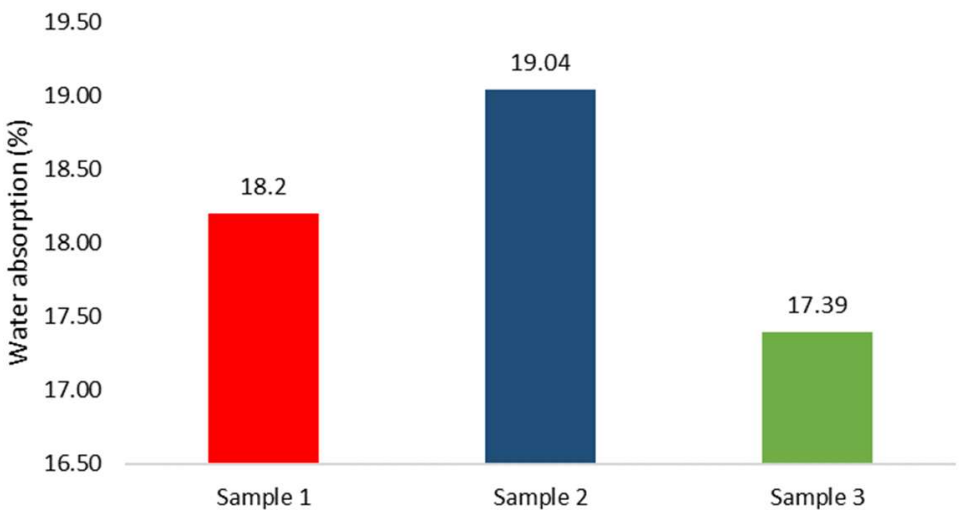

FIGURE 7. Mean water absorption of the sampled material.

The water absorption values were satisfactory for all mixtures. However, the values for the mixtures containing SCBA were higher than those of composition 3, which did not contain SCBA. This result was due to the increase in porosity and void index of bricks containing SCBA.

Almeida et al. (2015) reported that the increase in the water absorption index of soil might be caused by variations in the amount of ash, micropores, and macropores in its composition. Because ash more effectively fills smallerdiameter pores but not larger-diameter pores, there is a predominance of empty pores with a larger diameter in the materials containing a higher percentage of ash, resulting in higher water absorption.

In the present study, the mean water absorption was $17.39 \%, 18.20 \%$, and $19.04 \%$ in materials without SCBA and those containing $40 \%$ and $30 \%$ of SCBA, respectively. The mean water absorption in the material containing $40 \%$ SCBA was lower than that of the material containing $30 \%$ SCBA but higher than that of the reference material, evidencing the increased water absorption in materials containing ash compared to the reference material.

Therefore, the desired filler effect with the addition of natural ash to the brick mixture did not occur because the water absorption index was increased in the bricks with the addition of SCBA.

\section{CONCLUSIONS}

The analysis of the tested properties in soil-cement bricks with and without SCBA indicates that:

The addition of untreated SCBA to soil-cement bricks is not recommended. The desired filler effect does not occur because of the presence of impurities and variable granulometry, among other factors, contributing to the decrease in the quality of the mixtures.

The combination of SS and CS in bricks was not satisfactory, and the compressive strength of these bricks was lower than that established by the norm even without the addition of SCBA.

The compressive strength of materials containing SCBA was lower than that established by the norm, preventing their effective use.

The results on water absorption indicate that the addition of SCBA without treatment increased the porosity of the bricks; however, the compressive strength of the material was within the established limits.

These results indicate that it is necessary to pre-treat the SCBA to maintain or improve the physical properties of the bricks, reduce the use of natural resources, and promote environmental sustainability by using materials that would otherwise be discarded. 


\section{REFERENCES}

ABNT - Associação Brasileira de Normas Técnicas (2013a) NBR 10833: Fabricação de tijolo e bloco de solocimento com utilização de prensa manual ou hidráulica Procedimento. ABNT, 3p.

ABNT - Associação Brasileira de Normas Técnicas (2013b) NBR 10834: Bloco vazado de solo-cimento sem função estrutural - Requisitos. ABNT, 5p.

ABNT - Associação Brasileira de Normas Técnicas (2013c) NBR 10836: Bloco de solo-cimento sem função estrutural - Análise dimensional, determinação da resistência à compressão e da absorção de água — Método de ensaio. ABNT, 4 p.

Almeida FCR, Sales A, Moretti JP, Mendes PCD (2015) Sugarcane bagasse ash and (SBAS): Brazilian agroindustrial by-product for use in mortar. Construction and Building Materials 82: 31-38. DOI:

https://doi.org/10.1016/j.conbuildmat.2015.02.039

Berenguer RA, Silva FAN, Monteiro ECB, Lins CS, Lima A (2016) Effect of Sugarcane Bagasse Ash as Partial Replacement of Cement on Mortar Mechanical Properties. Electronic Journal of Geotechnical Engineering 21:45774586.

Bezerra ACS, Saraiva SLC, Lara LFS, Castro LWA, Gomes RC, Rodrigues CS, Ferreira MCNF, Aguilar MTP (2017) Effect of partial replacement with thermally processed sugarcane bagasse on the properties of mortars. Revista Matéria 22(1). DOI: http://dx.doi.org/10.1590/s1517707620170001.0117

Castro MAM, Costa FG, Borba SC, Neto EF, Rabelo AA (2016) Avaliação das propriedades físicas e mecânicas de blocos de solo-cimento formulados com coprodutos siderúrgicos. Revista Matéria 21(3):666-676. DOI: http://dx.doi.org/10.1590/s1517-707620160003.0064

Cortez L, Magalhães P, Happi J (1992) Principais produtos da agroindústria canavieira e sua valorização. Revista Brasileira de Energia 2(2):12-18

Estabragh AR, Beytolahpour I, Javadi AA (2011) Effect of Resin on the Strength of Soil-Cement Mixture. Journal of Materials in Civil Engineering 23(7):969-976

Faria KCP, Gurgel RF, Holanda JNF (2012) Recycling of sugarcane bagasse ash waste in the production of clay bricks. Journal Of Environmental Management 101:7-12.

Fernandes SE, Tashima MM, Moraes JCB, Istuque DB, Fioriti CF, Melges JLP, Akasaki JL (2015) Cinza de bagaço de cana-de-açúcar (CBC) como adição mineral em concretos para verificação de sua durabilidade. Revista Matéria 20(4):909-923. DOI:

http://dx.doi.org/10.1590/s1517-707620150004.0096

Ferrari VJ, Souza AHC, Baltazar HP, Dotto W, Neto JGV (2014) Tijolos vazados de solo-cimento produzidos com solo da Região do Arenito Caiuá do Paraná. Ambiente Construído 14(3):131-148. DOI: http://dx.doi.org/10.1590/S167886212014000300011

Geerthana R, Gnanasoundari J, Madheswari T, Vetriselvi K, Selvarani S (2016) Evaluation of sugarcane bagasse ash as a partial replacement of cement in concrete. International Journal of Advanced Research Trends in Engineering and Technology 3(2):666-672.
Gilio L, Castro NR (2016) Avaliação de aspectos limitantes ao crescimento do etanol e o setor sucroenergético no Brasil. Revista Eletrônica de Energia 6(1):57-74.

Kazmi SMS, Abbas S, Munir MJ, Khitab A (2016) Exploratory study on the effect of waste rice husk and sugarcane bagasse ashes in burnt clay bricks. Journal of Building Engineering 7:372-378. DOI: https://doi.org/10.1016/j.jobe.2016.08.001

Leonel RF, Folgueras MV, Valentina LVOD, Prim SR, Prates GA, Caraschi JC (2017) Characterization of soil-cement bricks with incorporation of used foundry sand. Cerâmica 63(367):329-335. DOI: http://dx.doi.org/10.1590/0366-69132017633672131

Machado AO, Araújo JA (2014) Avaliação de Tijolos Ecológicos Compostos por Lodo de ETA e Resíduos da Construção Civil. In: XI Simpósio de Excelência em Gestão e Tecnologia. Resende, Associação Educacional Dom Bosco.

Muñoz VP, Morales OMP, Letelier GV, Mendívil GMA (2016) Fired clay bricks made by adding wastes: Assessment of the impact on physical, mechanical and thermal properties. Construction And Building Materials 125:241252. DOI: https://doi.org/10.1016/j.conbuildmat.2016.08.024

Novacana (2016) MS fecha safra 2015/16 em 48,5 mi de t de cana e já projeta crescer $7,3 \%$. Novacana. Available in: https://www.novacana.com/n/cana/safra/ms-fecha-safra-1516-48-5-mi-t-cana-projeta-crescer-7-3-080416/. Accessed: Nov 25, 2016.

Rodrigues LP, Holanda JNF (2013) Influência da incorporação de lodo de estação de tratamento de água (ETA) nas propriedades tecnológicas de tijolos solocimento. Cerâmica 59(352):551-556. DOI: http://dx.doi.org/10.1590/s0366-69132013000400010

Silva VF, Brito KSA, Nascimento EC, Farias SAR (2014) Produção de tijolo ecológico para construção de residência no semiárido. Revista Educação Agrícola Superior 29(1):41-44. DOI: http://dx.doi.org/10.12722/0101-756x.v29n01a11

Sivakumar M, Mahendran N (2014) Experimental Studies the Strength and Cost Analysis of Concrete using Bagasse Ash. International Journal of Engineering Research \& Technology. 2(4):926-933.

Tommaselli MAG, Lima AV, Tsuji ER, Machado CAC, Alves AL (2011) Alternativa de utilização sustentável do resíduo cinza, oriunda da queima do bagaço da cana-deaçúcar, incorporando-a ao concreto como agregado. In: XXXI Encontro nacional de engenharia de produção. Belo Horizonte, Associação Brasileira de Engenharia de Produção, p. 1-9.

Valenciano MCM, Freire WJ (2004) Características físicas e mecânicas de misturas de solo, cimento e cinzas de bagaço de cana-de-açúcar. Engenharia Agrícola 24(3):484-492. DOI: http://dx.doi.org/10.1590/S0100-69162004000300001 